\title{
Socio-economic and environmental impacts of COVID-19 pandemic in Pakistan-an integrated analysis
}

\author{
Rizwan Rasheed ${ }^{1}$ (D) $\cdot$ Asfra Rizwan ${ }^{1} \cdot$ Hajra Javed $^{1} \cdot$ Faiza Sharif $^{1} \cdot$ Asghar Zaidi $^{2}$ \\ Received: 19 October 2020 / Accepted: 11 December 2020 / Published online: 6 January 2021 \\ (C) The Author(s), under exclusive licence to Springer-Verlag GmbH, DE part of Springer Nature 2021
}

\begin{abstract}
The COVID-19 pandemic has affected about 210 countries with more than 67 million confirmed cases and over 1.5 million deaths across the globe including Pakistan. Considering the population density, health care capacity, existing poverty and environmental factors with more than 420,000 infected people and about 8300 plus mortalities, community transmission of the coronavirus happened rapidly in Pakistan. This paper analyses the short- and long-term effects of COVID-19 peak on the socio-economic and environmental aspects of Pakistan. According to the estimates, an economic loss of about $10 \%$, i.e. 1.1 trillion PKR, will be observed in the FY 2021. Certain pandemic impediment measures like lockdowns, social distancing and travel restrictions taken by the Government have been thoroughly analysed to determine how they impacted the livelihoods of nearly 7.15 million workers. Consequently, a rise of $33.7 \%$ of poverty level is projected. While many negative impacts on primary, secondary and tertiary sectors of the economy such as agriculture, education and health care are observed, a drastic improvement in air quality index of urban centres of the country has been recorded amid lockdowns. With current economic crisis, fragile health care system and critical health literacy, a well-managed and coordinated action plan is required from all segments of the society led by the public authorities. Thorough assessment of COVID-19 scenario, management and control measures presented in this study can be assistive for the provision of policy guidelines to governments and think tanks of countries with similar socio-economic and cultural structure.
\end{abstract}

Keywords Coronavirus $\cdot$ Disease outbreak $\cdot$ Disaster preparedness $\cdot$ Environment $\cdot$ Air quality $\cdot$ Lockdown

\section{Introduction}

Viral diseases have continued to emerge and present a significant threat to public health, according to the "World Health Organization" (WHO). Wuhan, the largest metropolitan area in Hubei province of China, reported for the first time clusters of cases which had unexplained low respiratory infections to the WHO country office on December 31, 2019. The beginning of these symptomatic individuals can be traced back to

Responsible Editor: Lotfi Aleya

Rizwan Rasheed

rizwanrasheed@gcu.edu.pk; riz_mian@hotmail.com

1 Sustainable Development Study Centre, Government College University Lahore, Katchary Road, Lower Mall, Lahore 54000, Pakistan

2 Office of the Vice Chancellor, Government College University Lahore, Lahore, Pakistan the start of December 2019, according the survey of published literature (Cascella et al. 2020; Sahin et al. 2020). Since the causative agent was not identified, therefore, these first cases were termed as "pneumonia of unknown aetiology." After thorough investigation of the intensive outbreak by the "Chinese Centre for Disease Control and Prevention" (CDC), the aetiology of the illness was recognized as pneumonia caused by a novel virus. The virus belongs to the coronavirus (CoV) family and was named as the novel coronavirus pneumonia and was termed as 2019-nCov by the Chinese researchers (Zhu et al. 2020). Later on, it was named as "severe acute respiratory syndrome coronavirus-2" by the "International Committee on Taxonomy of Virus" ( $\mathrm{Zu}$ et al. 2020). On February 11, 2020, the WHO named the pneumonia as coronavirus disease-19 also known as COVID-19 (Li et al. 2020; Waris et al. 2020).

On January 30, 2020, the WHO declared the outbreak of coronavirus disease as the sixth public health of emergency services. This outbreak is not the first as previous outbreaks of coronavirus have occurred. These include the severe acute 
respiratory syndrome coronavirus (SARS-CoV) in 20022003, and most recently, in 2012 the Middle East respiratory syndrome coronavirus (MERS-CoV) was identified for the first time in Saudi Arabia. COVID-19 is, therefore, being considered as the third coronavirus outbreak which has affected over 200 countries all over the globe including Pakistan (Waris et al. 2020; Zhou et al. 2020).

On March 11, 2020, the number of cases reported outside China were 13 times more than that reported in China, i.e. 118,000 cases in 114 countries and more than 4000 deaths; therefore, COVID-19 was declared as a pandemic by the WHO (Cascella et al. 2020; Di Gennaro et al. 2020). As per the current statistics reported by the WHO, there are 67,618,431 confirmed cases of COVID-19 globally, and 1,544,985 mortalities have been reported (WHO 2020b). As of now, the USA, followed by India, Brazil, Russia, France and Italy have reported the highest number of positive cases (Table 1) (GoP 2020). If compared with the developed countries which are having state-of-the-art health care and testing facilities, the performance of Pakistan in flattening the COVID-19 curve during the first wave has been quite astonishing. In the mid-August, the global COVID-19 cases surpassed 23 million with more than 810,000 fatalities, but in Pakistan, around 292,000 infected cases were recorded with 6200 mortalities. This has been attributed to the smart lockdown scheme launched by the government which involved identification of COVID hotspots across Pakistan and isolating those specific areas. The second factor is the high youth population in Pakistan. The countries which have been at the worst hit had population with an average age of 35-45. Moreover, various surveys have highlighted that a few cities and not the whole country are showing signs of widespread herd immunity. This phenomenon is helping the population to cope with the novel coronavirus (Kermani 2020).

The bordering countries of Pakistan have been severely hit by the coronavirus such as China which is the epicentre of COVID-19 having 4634 deaths. While Iran situated in the North also has very high number of fatalities which were recorded as 50,594. The very first case of COVID-19 in Pakistan was reported by the "Ministry of Health, Government of Pakistan" on February 26, 2020, in Karachi (Ali et al. 2020; Malik 2020). While on the same day "Pakistan Federal Ministry of Health" confirmed another case in the federal capital, Islamabad. Within a span of 15 days, the number of suspected cases was reported to be 471 in which the confirmed cases of COVID-19 were 20 (4.25\%). The province of Sindh had the highest number of cases, i.e. 14 followed by 5 in Gilgit-Baltistan and 1 in Baluchistan. All the positive cases were reported to have recently travelled to Iran, Syria and London (Waris et al. 2020; Saqlain et al. 2020).

The geographical location of our country and the constant increase in the number of COVID-19-infected cases suggested that there was a dire need of strategic preparedness and prompt actions were required to control the situation before it becomes worse. The "Ministry of National Health Services, Regulation and Coordination Pakistan" on February 12, 2020, presented a "National Action Plan" in response to COVID-19 so that the spread of the virus can be controlled. Furthermore, its objective is to strengthen the emergency preparedness of the community and the country as a whole so that a timely and effective response could be made in respect to the evolving situation regarding COVID-19. The government of Pakistan to date has taken various steps (NIH 2020; Waris et al. 2020).
Table 1 Statistics of top 15 COVID-19-affected countries (as of December 6, 2020)

\begin{tabular}{lllll}
\hline & Country & Confirmed cases & Total deaths & Transmission classification \\
\hline 1 & USA & $15,159,529$ & 288,906 & Community transmission \\
2 & India & $9,678,600$ & 140,620 & Clusters of cases \\
3 & Brazil & $6,603,540$ & 176,962 & Community transmission \\
4 & Russian Federation & $2,488,912$ & 43,597 & Clusters of cases \\
5 & France & $2,292,497$ & 55,155 & Community transmission \\
6 & Italy & $1,728,878$ & 60,078 & Community transmission \\
7 & United Kingdom & $1,723,242$ & 61,245 & Community transmission \\
8 & Spain & $1,699,145$ & 46,252 & Community transmission \\
9 & Argentina & $1,463,110$ & 39,770 & Community transmission \\
10 & Colombia & $1,371,103$ & 37,808 & Community transmission \\
11 & Germany & $1,185,093$ & 19,166 & Community transmission \\
12 & Mexico & $1,175,850$ & 109,717 & Community transmission \\
13 & Poland & $1,067,870$ & 20,181 & Community transmission \\
14 & Iran & $1,051,374$ & 50,594 & Community transmission \\
15 & Peru & 973,912 & 36,274 & Community transmission \\
\hline
\end{tabular}


Fig. 1 COVID 19 outbreak figures (as of October 6, 2020) of Pakistan

\section{Current situation}

A total of 420,294 cases have been reported by the "Ministry of Health, Government of Pakistan" in the country out of which 8588 are active cases and 6523 deaths as of October 6, 2020. Since now Pakistan is facing the 2nd COVID-19 peak, the active cases have risen to 55,354 and 8398 deaths have occurred. The total number of recovered cases recorded was 300,616 whereas 3,702,607 tests have been conducted all over the country as of October 6, 2020. Currently the recovered cases reported are 356,542 with 5,794,242 total number of tests. (Fig. 1). The highest number of positive cases has been reported by the province of Sindh, followed by Punjab, Khyber Pakhtunkhwa (KPK), Federal (ICT), Baluchistan, Azad Jammu and Kashmir and Gilgit-Baltistan. The highest number of mortalities has been reported by the province of Punjab followed by Sindh and KPK. Sindh has the highest number of recovered patients with Punjab second and KPK third. The details have been summarized in Table 2. The mortality rate in reference to the positive cases in Pakistan is $2.0 \%$ with $95.2 \%$ recovery rate (as of October 6,2020 ). Currently during the second peak, the recovery rate has dropped to $84.8 \%$. (GoP 2020).
In an attempt to understand the turmoil effects of the novel coronavirus pandemic on the society, environment and the economy, this study summarizes the socio-economic and environmental impacts of COVID-19 in Pakistan. Until date no such study has been conducted which highlights the integrated socio-economic and environmental impacts resulted due to the peak of the global viral outbreak in Pakistan. This study aims to forecast the possible short- and long-term effects of the pandemic on the emerging economy, society and the environment by considering the current discussions. The aim is to analyse the peak period of the COVID-19 pandemic and the subsequent lockdown strategy adopted to curb the spread so to fill the current knowledge gap by providing a thorough insight of the current socio-economic crises being faced by the resource-limited settings of Pakistan. This assessment can prove to be useful for the government, policymakers and practitioners of Pakistan as well as of countries having similar socio-economic and cultural structure like Pakistan.

This paper is structured into 8 main sections with first section being the "Introduction". After the Introduction, the "COVID-19 vs previous epidemics - comparative clinical and economic analysis" section compares COVID-19 with previous epidemics drawing a comparative clinical and
Table 2 Current province wise COVID-19 outbreak figures (as of December 6, 2020)

\begin{tabular}{lllll}
\hline & Total confirmed cases & Active cases & Mortalities & Recovered cases \\
\hline Punjab & 123,762 & 21,189 & 3177 & 99,396 \\
Sindh & 184,486 & 21,886 & 3019 & 159,581 \\
Baluchistan & 17,466 & 561 & 169 & 16,736 \\
KPK & 49,676 & 4010 & 1413 & 44,253 \\
Islamabad & 32,816 & 6079 & 341 & 26,396 \\
Gilgit-Baltistan & 4732 & 152 & 98 & 4.482 \\
Azad Kashmir & 7356 & 1477 & 181 & 5.698 \\
\hline
\end{tabular}


economic analysis. The "Health system and response in Pakistan" section highlights the health care system of Pakistan and its subsequent response to the current pandemic. The "State of environment and pollution" section presents the effect of the pandemic on the environment and pollution. The "Agriculture sector and food security" section is based on the impact faced by the agricultural sector and consequent food security issue, whereas "Poverty and labour market" is addressed in the "Poverty and labour market" section. "Socioeconomic impacts" due to the COVID-19 pandemic have been analysed in the "Socio-economic impacts" section. The "COVID-19: measures and lessons" section presents the containment measures and lessons learnt for Pakistan. The "Conclusion and the way forward" section concludes the study while highlighting what should be our way forward with this pandemic.

\section{COVID-19 vs previous epidemics-comparative clinical and economic analysis}

Drawing comparative inferences between previously encountered wide-reaching epidemics and the newly emerging outbreaks holds critical significance for the health sector and economic policymakers alike. These relative evaluations provide baseline guidance for assessing the efficiency and community response to the existing policy frameworks in controlling such biological risks. This also leads towards making certain needful improvisations in the important state sectors as a proactive response for effectually controlling similar outbreaks in future, based on the lessons from previous experiences (Lai et al. 2020). The novel COVID-19 has been regarded as a global pandemic by the World Health Organization (WHO) on March 11, 2020, considering its wide-scale impacts and mortalities. The previous viral outbreaks including the "severe acute respiratory syndrome" (SARS) in 2003, "Middle East respiratory syndrome" which occurred in 2012 and Spanish flu (H1N1) which affected the human community from 1918 to 1919 all involved closely related strains of influenza virus that were also responsible for pneumonia (Baldo et al. 2016; Barro et al. 2020; Liu et al. 2020).

While all these epidemic events adversely impacted the humankind in terms of thousands of lives lost and economic setbacks, but only Spanish flu outbreak in 1918-1919 can be regarded as a true pandemic which can be related to COVID19 in disease intensity and scale of infection. The viral flu of the twentieth century which resulted in loss of approximately $30 \%$ of the global population had held the research interests of epidemiologists around the world for decades in controlling its contagion effects and lasting ramifications (Lai et al. 2020; Lilley et al. 2020; Verikios 2020). With its first case reported in a Spanish newspaper, this flu became a world-reaching pandemic due to its exponential transmission in the soldiers returning to their homelands at the end of the World War I. Affecting more than 200 countries of the world, this pandemic of the twentieth century can be regarded as the closest parallel of the modern coronavirus in view of its severity and global outreach. Despite of the presence of extensive research data on previous viral epidemics, the scale of impact of COVID-19 is still unprecedented (Di Gennaro et al. 2020; Liu et al. 2020).

\section{Epidemiological analysis}

Studying the human response and epidemiological patterns of previous epidemic events of the twentieth and twenty-first centuries can help in anticipating the trajectory of the recent pandemic. Moreover, it can provide factual inferences for controlling the exponential transmission rate while devising new combinations of different medications with high possible efficiency. First case of COVID-19 was diagnosed in Wuhan, China, in the end of 2019 and then the number of infected cases and mortalities multiplied within days. The disease has now been controlled to a major extent in China; however, it has impacted 85,482 people and took 4634 lives in China alone as of May 14, 2020, with a worldwide mortality rate nearing that of the Spanish flu. Moreover, the virulence of this novel viral strain has been observed to be significantly higher than any previous flu epidemics encountered by the human history (Liu et al. 2018; Sun et al. 2020; Rothan and Byrareddy 2020). In addition to this, two other epidemiological variables considered crucial for analysing disease pattern include "viral velocity" and "mortality rate." When comparing with SARS and MERS viruses, the COVID-19 has been inferred to have $10 \%$ and $35 \%$ less mortality rate and 20 and 3 times less transmission rate than SARS and MERS as expressed in Table 3 (Adhikari et al. 2020; Baldo et al. 2016; Liu et al. 2020; MacIntyre 2014).

\section{Economic analysis}

Analysis of the economic repercussions of previous epidemic events like SARS, MERS and the Spanish flu which has been recognized as pandemic similar to COVID-19 unfold important lessons. The socio-economic consequences included decreased the demand of goods and services, supply chain disruption, employment and income loss. However, in 2003 after the cases of SARS were controlled, a pronounced elevation in the demand rate was observed, and the same is expected at the end of this year if the COVID-19 spread is successfully controlled. Having said that, many economists express that in view of current uncertainty in disease control, it is very early to comment on the employment rate and demand and supply trajectory post-COVID-19 (Hassan et al. 2020). 
Table 3 Comparative analysis of COVID-19 with previous flu outbreaks in terms of primary epidemiological parameters

\begin{tabular}{llllll}
\hline $\begin{array}{l}\text { Epidemic } \\
\text { event }\end{array}$ & $\begin{array}{l}\text { Year of } \\
\text { outbreak }\end{array}$ & $\begin{array}{l}\text { Infected } \\
\text { cases }\end{array}$ & Fatalities & $\begin{array}{l}\text { Mortality rate } \\
(\%)\end{array}$ & $\begin{array}{l}\text { Transmission level (avg. no. } \\
\text { of persons) }\end{array}$ \\
\hline Spanish flu & 1918 & $500,000,000$ & $39,000,000$ & 2 & $1.4-1.6$ \\
SARS & 2003 & 8098 & 774 & 10 & $2-5$ \\
MERS & 2012 & 2494 & 858 & 35 & $0.6-1.3$ \\
COVID-19 & 2019 & $67,493,598$ & $1,543,629$ & 2.2 & $2-6.47$ \\
\hline
\end{tabular}

The impact of environmental conditions on transmission and fatality rate of previous flu outbreaks has also been comparatively investigated. A similar trend was observed in terms of air pollution, as the urban centres have high concentration of positive cases in all previous flu outbreaks. Thus, a direct relation was inferred between disease spread and poor air quality which places the urban regions at high risk. The same drift has been observed in case of this recent pandemic as there is high fatality rate in megacities of China, the USA, Italy and Spain. To anticipate the macro-economic implications in view of previous pandemics, the decrease in GDP has been analysed, providing an average decline rate of about $10 \%$ post 1918 flu outbreak. The impact of COVID-19 on global GDP has been depicted in Fig. 2; however, the values reveal that the impacts are not of that adversity level until date, as observed in 2008-2009 fiscal crisis. The economically stable nations of the world are forecasted to encounter a GDP growth decrease of $7.8 \%$ including the USA, where the IMF has projected a decline of $5.9 \%$. In the case of European countries, the GDP growth rate is forecasted to decrease by $7.5 \%$ while in developing countries with emerging economies a $2 \%$ decrease is anticipated. However, the economy in China, India, Pakistan and Indonesia will reflect an increase in GDP in the final quarter of 2020. It has also been inferred that the global fiscal deficits will require a long time to recover post-COVID-19 control. In the second quarter of 2021, a fragmental recovery period can be expected in GDP growth; however, that would be far below than the pre-pandemic rate (IMF 2020; OECD 2020; WEO 2020).

Although the modern viral strain does not appear to be as fatal in comparison to previous epidemics like SARS and MERS, it has become a global concern with drastically increasing transmission and fatality rate surpassing those of the pandemic of the previous century, i.e. Spanish flu in 1918-1919. At this point, accurately predicting the trajectory of the positive cases is not possible; however, the scale of socio-economic and geopolitical ramifications can be foreseen. The worldwide decreasing trend in petroleum, diesel and fuel oil prices owing to the cessation of industrial and transport activities has initiated a price war between the USA and Saudi Arabia. The lessons from the past epidemiological experiences should always be taken into consideration while devising better control mechanisms and mitigating the consequences of long-term economic destabilization (McKee and Stuckler 2020; Sharif et al. 2020).

\section{Health system and response in Pakistan}

Characterizing the ramifications of previously prevalent diseases on the public health care sector is quite convenient. However, projecting the scale of impacts of newly emerged viral or bacterial strains having unforeseen clinical impacts, transmission levels and mortality rates is often a strenuous

Fig. 2 Percent variation in global GDP rate from 2005 to 2021

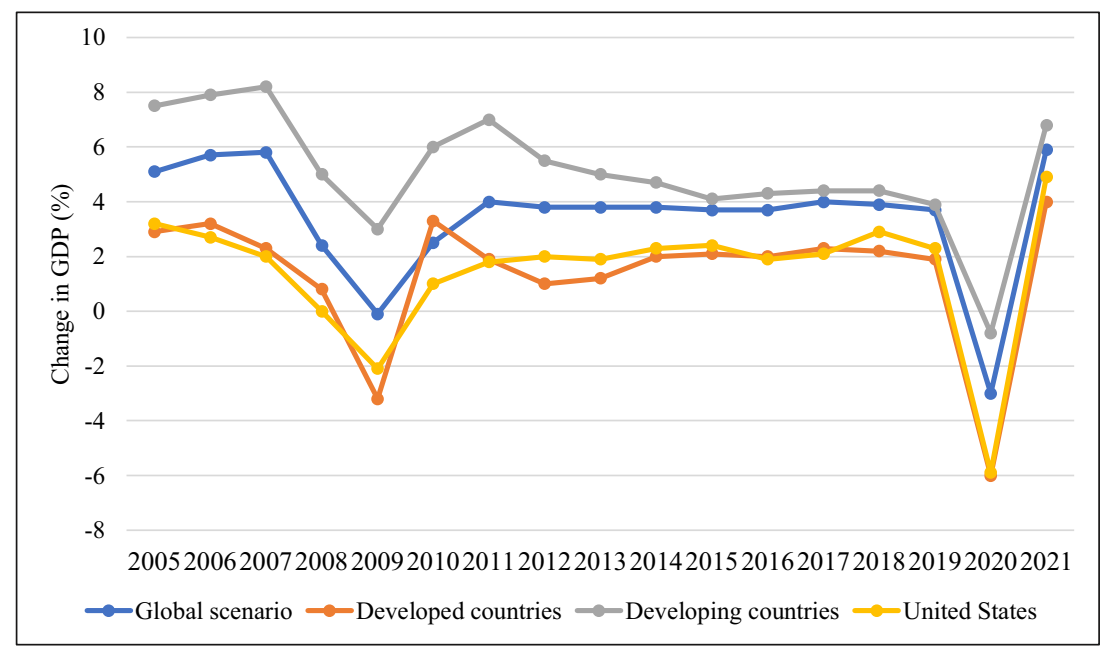


Table 4 Statistical analysis of the health care facilities for controlling COVID-19 in Pakistan

\begin{tabular}{llllc}
\hline Province & Quarantine facilities (beds) & Isolation wards (beds) & \multicolumn{2}{c}{ Testing capacity (per day) } \\
\cline { 4 - 5 } & & & Public & Private \\
\hline Punjab & 10,948 & 955 & 5500 & 8960 \\
Sindh & 2100 & 151 & 6380 & 5600 \\
Baluchistan & 5897 & 534 & 1550 & \\
KPK & 2760 & 856 & 2950 & 1800 \\
Islamabad & 350 & 10 & 2050 & 5300 \\
Gilgit Baltistan & 972 & 126 & 400 & \\
Azad Kashmir & 530 & 310 & 700 & \\
Total & 23,557 & 2942 & 19,530 & 21,660 \\
\hline
\end{tabular}

task. In these circumstances, it is crucial to anticipate and manage the increasing health expenditures and relevant resources, not only during the disease outbreak but also for catering lasting post-disease costs (Stratford 2020; Junaidi 2020). Only $2 \%$ of the GDP in Pakistan is allocated for the public health sector, which is far below the worldwide average of $11.6 \%$ (WHO 2020a).

As hospitals are inundating with COVID-19 patients and constantly pacifying fatality rates, Pakistan's feeble health care sector is invigorating for an impending peak of cases. The country is rapidly taking measures for strengthening the public health system in order to effectively cope with the pace of pandemic spread. The important measures include establishing new laboratories and importing ventilators, testing kits and personal protective equipment for health professionals. The number of infected cases observed an exponential increase in May-July, surpassing China, the epicentre of COVID-19. Although the public sector representatives claimed that the condition of coronavirus spread is under manageable limits, the health care officials kept on pleading that within the existing financial and technical capacity, further increase in cases will result in collapse of the health sector (Agency 2020). Table 4 presents the province-wise statistics of medical and testing facilities available for coping with the pandemic in Pakistan.

According to the report by the World Bank, Pakistan had a health care expenditure of $40 \$$ per capita per year in 2016. On contrary to this, the neighbouring countries including India and Iran had relative figures of $62 \$$ and $415 \$$ per capita as depicted in Fig. 3. Despite of allocating significant share of national budget for health care sector, Iran has encountered that severe clinical complications are managing the COVID19 cases (Pakistan Today 2019; WHO 2020a). This further adds to the concern of policymakers in Pakistan during such pandemics. Moreover, viewing the inadequacies of global health care systems, it is a deep concern for a country with such resource-constrained settings, to scale-up the disease detection and treatment facilities for efficiently and promptly addressing wide-reaching outbreaks of the deadly disease (IGC 2020).
Fig. 3 Per capita expenditure of health by the government in Pakistan and its neighbouring countries

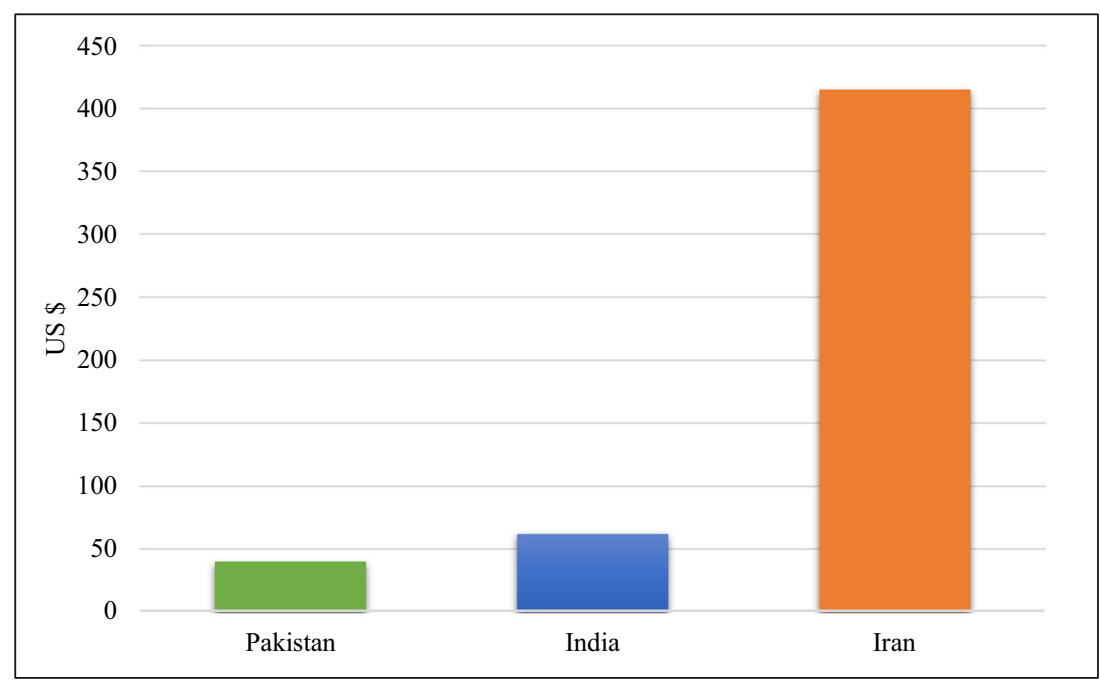




\section{State of environment and pollution}

The lockdown around the world has stifled the routine activities and has restricted many services including transportation, industrial and agricultural production which were attributed as major contributors to environmental pollution (Henriques 2020). While the disease outbreak has taken more than 1600 lives in Pakistan with accompanied negative ramifications impacting communities in the form of employment loss and financial breakdown, some positive impacts have been observed on the air quality. According to the World Air Quality report 2019, high air pollution levels were evaluated throughout the South Asian countries with Bangladesh, Pakistan and India ranking among the top five countries having worst air quality. However, over the last few months amid the coronavirus crisis, air quality across the world has reported considerable improvement as the major activities requiring immense fossil fuels burning have been halted to some extent (Pakistan Today 2020; Qazi 2020). Over the past few months during the lockdown period, the air quality data obtained from different major cities of Pakistan has reported considerable decrease in the concentration of primary air pollutants, e.g. NOx, SOx, $\mathrm{CO}_{2}$ and $\mathrm{PM}_{2.5}$ and $\mathrm{PM}_{10}$, while a gradual increase has been observed post lockdown. The air quality index level of four major cities from October 2019 to October 2020 has been presented in Table 5 (Abbasi 2020; CREA 2020; Pakistan Today 2020).

An important initiative has also been taken by the Pakistan's government for usefully indulging the labour and daily wagers that were not being able to continue their jobs owing to the lockdown and subsequent closure of various sectors. Some of these unemployed wagers have now been given employment opportunities as "jungle workers" in the

Table 5 Variation in the air quality index of major cities of Pakistan from October 2019 to October 2020

\begin{tabular}{lllll}
\hline Months & Karachi & Lahore & Islamabad & Peshawar \\
\hline October 2019 & 155 & 265 & 111 & 177 \\
November 2019 & 149 & 186 & 160 & 169 \\
December 2019 & 210 & 315 & 190 & 215 \\
January 2020 & 106 & 278 & 129 & 205 \\
February 2020 & 117 & 195 & 167 & 194 \\
March 2020 & 69 & 51 & 67 & 77 \\
April 2020 & 60 & 49 & 65 & 75 \\
May 2020 & 78 & 73 & 69 & 70 \\
June 2020 & 103 & 112 & 92 & 90 \\
July 2020 & 120 & 129 & 86 & 102 \\
August 2020 & 198 & 176 & 109 & 112 \\
September 2020 & 200 & 201 & 102 & 117 \\
October 2020 & 204 & 178 & 110 & 124 \\
\hline
\end{tabular}

10 Billion Tree Tsunami programme, a plantation initiative of Pakistan. These types of "green or eco-friendly stimulus" human capital investments present an example of efficiently utilizing the monetary resources for helping the communities while proactively preparing the country to cope up with the next big threats ahead including climate change (WEF 2020). Nonetheless, such catastrophic events often result in proliferation in natural resources' demand, leading towards high agricultural and wildlife harvest rates as the governments may overlook environmental protection policies while prioritizing economic stability post-COVID-19 outbreak (Pakistan Today 2020).

The impact of environmental conditions on transmission and fatality rate of previous flu outbreaks has also been comparatively investigated. A similar trend was observed in terms of air pollution, as the urban centres have high concentration of positive cases in all previous flu outbreaks. Thus, a direct relation was inferred between disease spread and poor air quality which places the urban regions at high risk. The same drift has been observed in case of this recent pandemic as there is high fatality rate in megacities of China, the USA, Italy and Spain (Di Gennaro et al. 2020).

\section{Agriculture sector and food security}

Many countries are experiencing a difficult time in protecting their agriculture sector from the adverse consequences of pandemic considering the potential threats of food insecurity. For developing countries, food security has always been a crucial subject (Imran 2020). In 2018, it has been estimated that 37\% of the people in Pakistan are suffering from food insecurity issues. Sindh province, being the second largest agricultural producer in Pakistan, has $46 \%$ of population that lack access to basic nutritional facilities and is experiencing malnutrition issues including stunted growth (UNICEF 2018). In such critical scenarios, directing efforts to simultaneously address the disease spread and social protection are important.

The farming sector of Pakistan has not only served as a backbone for food security but has always been a major support to the economy, being the highest contributor to GDP. Pakistan is the 8th largest producer of wheat, 10th largest of rice, 5th of sugarcane and 4th largest producer of milk in the world. Even with this standing, only $63.1 \%$ of the population has adequate supply of food sources to be considered as "food secure" (UNICEF 2018). The agriculture sector in the country is facing various challenges including the recent pandemic which has disrupted the production by limiting the work force and restricting transport facilities for dispatching the harvested crops. Before the advent of this pandemic, the agriculture sector was sustaining the impact of wide-scale locust attack which has severely damaged various crops exerting economic 
stress on the associated farmers (Abid 2020; Ayra 2020; Imran 2020).

\section{Grains and pulses}

Wheat, being the staple food crop of Pakistan, is characterized in the group of 5 major export crops (cotton, wheat, rice, maize and sugar cane) that have a relative share of $4 \%$ in the GDP of the country. As most of the population depends on wheat and rice for basic nutritional needs, the impact of the current pandemic on their production levels needs to be analysed in terms of price fluctuations. Pulses occupying 5\% of the total cultivated area are regarded as an economical source of vegetable proteins for the poor communities which cannot afford red meat or white meat for fulfilling protein requirements. Figure 4 presents the variation in the prices of wheat, rice and pulses (masoor as it has the highest demand in the country). The price per $100 \mathrm{~kg}$ of wheat has been observed to be quite uniform until mid-June, but then a sudden increase has been observed. For pulses, a $24.7 \%$ decrease in price has been analysed. In the case of rice, initially a $6.6 \%$ increase in price has been observed, and after that, there is a declining trend until June, but again some increase has been seen in July (AIMS 2020; Anjum 2020).

\section{Fruits and vegetables}

Fruits and vegetables are usually at high risk in any agricultural crisis as these are perishable products having limited shelf life. Pakistan is one of the largest producers of mango with an annual yield of 1.7 million as of 2020. Mango is usually harvested in Sindh in the mid of May and in the first 2 weeks of June in Punjab. The primary concern this year was the unavailability of workers for harvesting the ripened fruit. The second major issue was limited means of transportation for transferring the harvested products into the retail markets for their domestic sale amid lockdown. This also impacted the export market as the exchange of goods between countries was temporarily suspended. The price variations per $100 \mathrm{~kg}$ are analysed from March 15 (the start of lockdown in Pakistan) to July 25, 2020, for 3 major vegetables, i.e. tomato, potato and onion, and 2 fruit types, i.e. apple and banana, as presented in Fig. 5. Those fruits and vegetables types are selected which show least seasonal production level fluctuation in these specified months (Abid 2020; AIMS 2020; Dawn News 2020).

\section{Poverty and labour market}

For a developing country which is already struggling at the societal and economic front, a wide-reaching pandemic like COVID-19 can further elevate the poverty level as unemployment and income deficit increases. The poverty and unemployment impact level can be viewed in terms of three relative GDP growth scenarios: high recession, i.e. $0-1.5 \%$ increase in GDP growth, medium recession, i.e. 1.5 to $2.5 \%$ decline in GDP rate, and low recession, i.e. 2.5 to $3.5 \%$ decrease in growth rate. It has been projected that the employment level in Pakistan will decrease from the baseline level of 3.86 million to 0.21 million (low economic recession scenario) reaching 0.62 million (high economic recession scenario) due the recent pandemic. Moreover, $33.7 \%$ increase in poverty level has been expected from the baseline value of $23.4 \%$ in case of low recession scenario, while a $44.2 \%$ and $58.6 \%$ elevation has been estimated in case of medium and high economic recession, as represented in Fig. 6 (ILO 2020b; Labour Force Survey 2018; Mamun and Ullah 2020). In addition to the poverty hike, a significant increase in the venerable population is also expected in Pakistan. This population include human communities earning income sufficient enough to keep them slightly above the poverty line, and longer periods of national economic instability will ultimately result in pushing them below the poverty line.
Fig. 4 Variation in the prices of wheat, rice and pulses per $100 \mathrm{~kg}$ in Pakistan from March 15, 2020, to July 25,2020

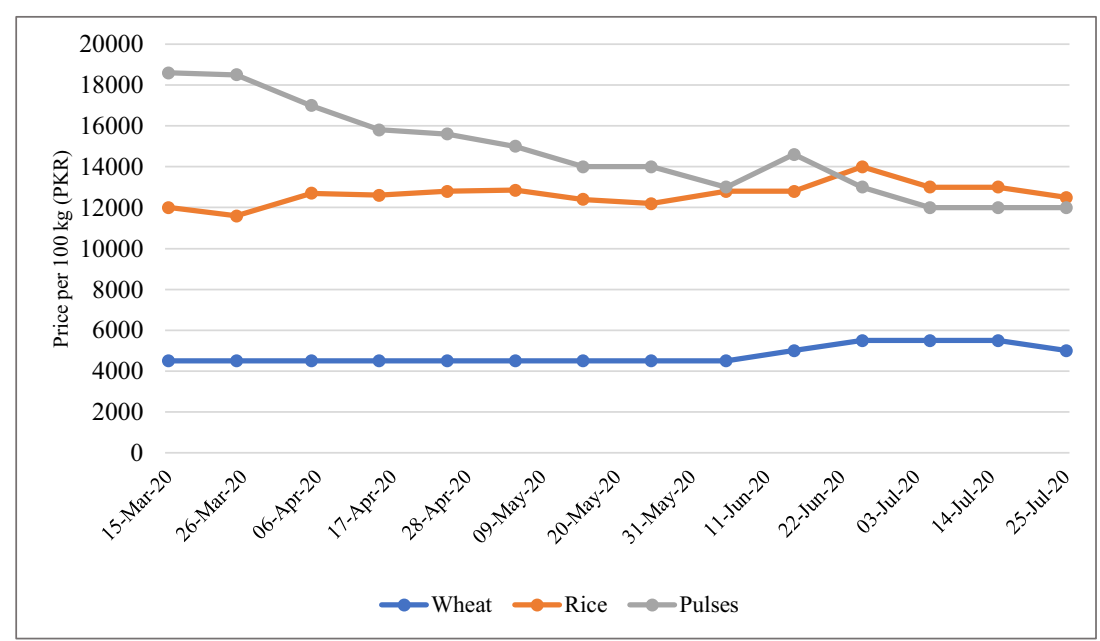


Fig. 5 Variations in prices of major vegetables and fruits in Pakistan from March 15 2020, to July 25, 2020. a Variations in prices of three major vegetables in Pakistan from March 15, 2020, to July 25, 2020. b Variations in prices of major fruits in Pakistan from March 15, 2020 to July 25, 2020
Fig. 6 Poverty rates at different economic recession scenarios in Pakistan
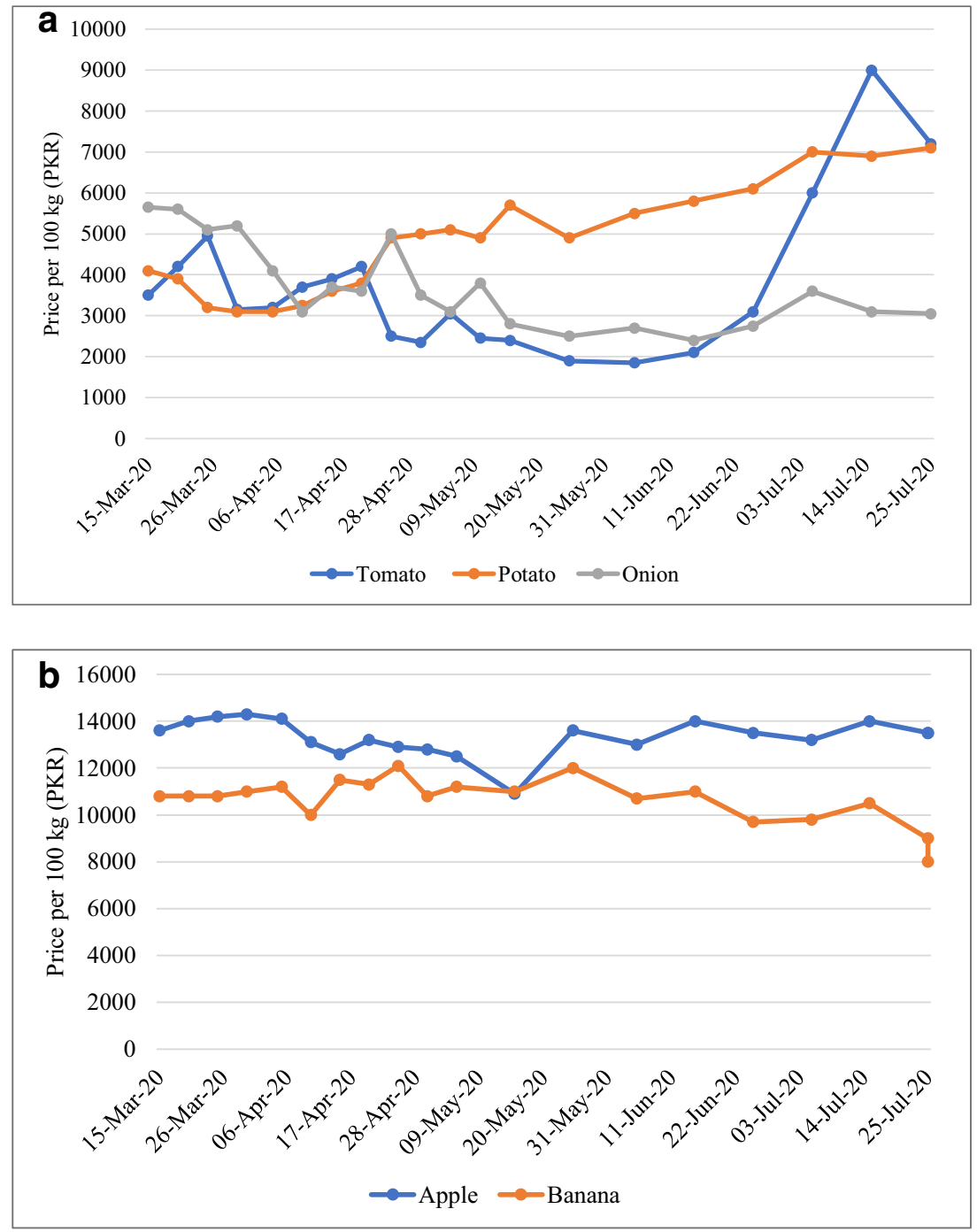


\section{Employment layoffs}

In this period of epidemiological and socio-economic crisis, effectively channelling the priority measures is a challenging task particularly for low-income developing countries like Pakistan. In the case of labour community, it has been crucial to choose between reduced disease exposure and financial stress. COVID-19-induced labour market backlash can be attributed to three major aspects including the decline in the number of employment opportunities owing to the closure of various state sectors. The second aspect can be described as the qualitative decline in employment type in terms of the absence of additional benefits or relief schemes in case of health problems or any other stress which is usually termed as social protection. The third aspect is the disproportionate influence on vulnerable sectors of the market which include the old-aged, women or people with physical impairments and small-scale private earners (ILO 2020a).

It is challenging for micro-enterprises that dominate the business sector in Pakistan to observe compliance with the standard operating procedures (SOPs) encapsulated by the government to ensure workers' protection. As a result, most of these enterprises have permanently suspended their employees after the lockdown. According to 2017 census, the total population of Pakistan was declared as 207 million and out of this, 20 million (i.e. 10\%) constitutes of people over the age of 50. Out of this 20 million, approximately 9 million are part of the labour force. The total labour community in the country is around 63 million (mostly of the age of 15 and above), and $6 \%$ of these have already lost their employment. The restaurants, hospitality sector, education institutes, small retail markets and the transport industry can be considered as the most adversely impacted sectors by the pandemic. Nearly
7.15 million workers are directly associated with these worstaffected sectors as per the Labour Force Survey (2018) (Ahmad 2020; Labour Force Survey 2018).

All the countries around the globe ceased the routine activities and services as an attempt to limit the mobility of people and thus preventing disease exposure. Lockdown has been considered as the only way of controlling the disease spread while flattening the virus escalation curve. As a result, in Pakistan the government also announced complete lockdown from March 23 to May 9, 2020, involving various sectors including educational institutes, businesses and public transport in all the provinces. As per the government guidelines, people employed in formal sector enjoyed job security and were also being paid during this lockdown, but those associated with informal sector had no access to all these benefits, and most of them were suspended (Malik et al. 2020). From the global instances, it was analysed that the daily wagers, street vendors, domestic helpers, people involved in courier and delivery services, cleaners and waste collection personnel possess the maximum disease exposure risk. The informal work force encountered joint issues of coronavirus infection and economic stress resulting in deprivation of food and daily necessities (Coibion et al. 2020; Inoue and Todo 2020).

Understanding the socio-economic consequences of different levels of social distancing and various stages of lockdown is crucial at the moment for devising efficient control measures. There are three basic stages of social distancing, i.e. stage I including limited restrictions, stage II which includes medium level of restrictions where major sectors are closed while some are still operational and stage III that includes complete shutdown of activities and total restriction on public movement. Table 6 characterizes the evaluated employment layoffs in different important sectors at the three major stages
Table 6 Sectoral employment layoffs at different stages of lockdown and social distancing

\begin{tabular}{lllll}
\hline Sectors & Vulnerably employed & Stage I & Stage II & Stage III \\
\hline Agriculture & $12,820,000$ & 0.00 & $2,560,000$ & $6,410,000$ \\
Fishing & 50,000 & 10,000 & 30,000 & 50,000 \\
Industry & $2,160,000$ & 220,000 & $1,510,000$ & $1,950,000$ \\
Electricity, fuel and water & 140,000 & 0.00 & 10,000 & 10,000 \\
Construction & 250,000 & 0.00 & 220,000 & 220,000 \\
Retail markets & $6,490,000$ & 650,000 & $4,550,000$ & $5,850,000$ \\
Food and accommodation & 600,000 & 120,000 & 540,000 & 540,000 \\
Transportation & $1,950,000$ & 200,000 & $1,760,000$ & $1,950,000$ \\
Property and land businesses & 200,000 & 0.00 & 100,000 & 140,000 \\
Public administration & 250,000 & 0.00 & 130,000 & 180,000 \\
Academic & 90,000 & 40,000 & 60,000 & 80,000 \\
Medical & 190,000 & 0.00 & 0.00 & 20,000 \\
Social work & 430,000 & 40,000 & 380,000 & 430,000 \\
Street vendors & 790,000 & 120,000 & 470,000 & 710,000 \\
Total & & $1,390,000$ & $12,330,000$ & $18,530,000$ \\
\hline
\end{tabular}


of social restrictions. At stage I, agriculture sector has almost no visible impact, while in stages II and III noticeable impact has been observed owing to the decrease in local and international demand. The worst impacted sectors during stage II lockdown include retail markets, transportation and manufacturing industry, major reason being the high ratio of vulnerable employees (informal workers). Shift from stage II to stage III is estimated to increase the layoffs by 10 folds (Nasir et al. 2020).

It is also important to anticipate the provincial scale of impact on vulnerable employees in various sectors for affectively developing relief packages for individual provinces depending on the potential layoffs as depicted in Table 7. Being the province with maximum population, Punjab has the highest number of work force including the vulnerably employed and thus requires sufficient relief funds to support these people. Pakistan had announced nationwide lockdown of somewhere between stages I and II in the end of March 2020 when the number of infected cases was rapidly increasing. This resulted in widespread economic pressure on the poor communities which were solely dependent on their daily wages for food. Viewing these adverse consequences, the government later decided to ease the lockdown on May 9, 2020, and gradually opened some employment sectors despite spiking COVID-19 cases. Another social distancing strategy which is currently in practice termed as "smart lockdown" has been developed. This involves identifying the COVID-19 hotspots and restricting activities in those identified areas. The trend of new coronavirus cases is being regularly monitored and if the situation deteriorates, new control measures will be introduced (Ahmad 2020; Faraz and Nasir 2020b).

\section{Socio-economic impacts}

Around the world, the regulatory agencies have apprehended lately that the biological threats not only impact the environmental health but also pose abiding wide-scale impedance in socio-economic parameters (OECD 2020). The impacts of such epidemic events on diverse state sectors, particularly those directly contributing towards the economic stability, are usually unseen instantly, but they lead to long-term adverse consequences. Such repercussions dominate the entire industrial arena with deep-routed consequences on local supply chains and national markets as the risk of health loss creates a sense of insecurity among masses (Duffin 2020; Nicola et al. 2020).

\section{Education sector}

Around the world, approximately 2.2 billion students are battling against COVID-19 and have been constrained to temporarily discontinue their formal education. The government of Pakistan has also suspended the formal academic activities and has provisionally shifted to virtual learning systems as an attempt for containment of coronavirus, controlling its wide-scale transmission. This transition towards virtual education necessitates timely large-scale allocation of resources for catering the academic requirements of approximately 47 million (according to the figures of year 2018) students which have discontinued their formal education (Fig. 7) (Ahsan 2020; Hyder 2020; Siddiqi 2020). This situation has resulted in increased drop-out rates as some small-scale educational institutions permanently ceased their activities due to shortage of funds.

With the dominance of virtual learning systems, the issue of digital divide raises concerns particularly in less technologically privileged countries like Pakistan where only $22 \%$ of the population have access to internet facilities. Most of the population especially those living in rural settings lack access to modern ICT equipment and internet connections. It is estimated that only $16 \%$ of the total population of Pakistan use smartphones having internet access while $53 \%$ people are using conventional mobile phones with basic features which lack internet connectivity options (as per the statistics of 2018). This is usually attributed to high poverty ratio and lack of technology infrastructure which limit the access of highend internet facilities and ICT equipment to students living in urban or semi-urban regions and usually belonging to middle and upper societal classes (Hyder 2020; Saeed 2020). The
Table 7 Province-wise sectoral employment layoffs for vulnerable employees in Pakistan

\begin{tabular}{llllll}
\hline & Punjab & Sindh & KP & Baluchistan & Total \\
\hline Daily wagers & $5,100,000$ & $3,400,000$ & $1,400,000$ & 300,000 & $10,100,000$ \\
Per piece wagers & $3,900,000$ & 500,000 & 300,000 & 200,000 & $4,900,000$ \\
Apprenticers & 200,000 & 0.0 & 100,000 & 0.0 & 300,000 \\
& \multicolumn{7}{c}{ Stage II layoffs } \\
Daily wagers & $6,100,000$ & $4,100,000$ & $1,700,000$ & 400,000 & $12,200,000$ \\
Per piece wagers & $4,700,000$ & 500,000 & 400,000 & 300,000 & $5,900,000$ \\
Apprenticers & 200,000 & 0.0 & 100,000 & 0.0 & 300,000 \\
\hline
\end{tabular}


Fig. 7 Number of students affected by the COVID-19induced closure of educational institutions in Pakistan (Hyder 2020)

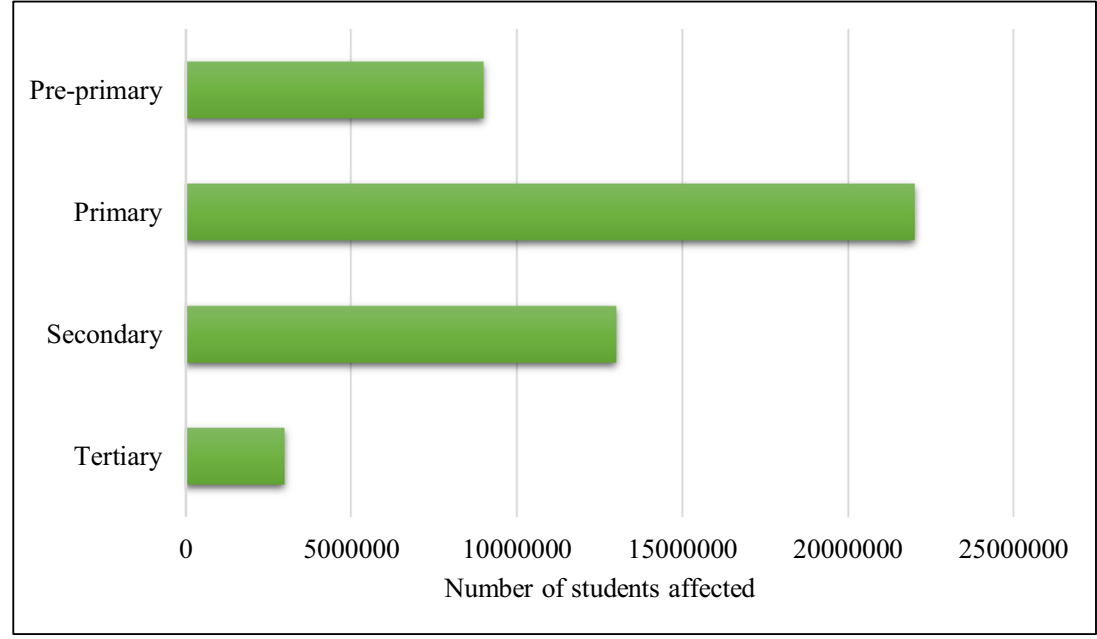

country has now shifted to hybrid system of education as educational institutions are being opened in phases where both online and classroom teaching are being practiced in an attempt to curb the spread of the virus and prevent an anticipated spike.

\section{Tourism industry}

The travel and tourism industry can be regarded as one of the worst impacted sectors by the current pandemic. As depicted in the Fig. 8, the United Nations World Tourism Organization (UNWTO) has estimated that the tourists count will decrease by 20 to $40 \%$ in the present year, accounting for a loss of approximately 350 to $450 \$$ billion in international tourism revenue (UNWTO 2020). The virus outbreak and consequent lockdown has not only directly impacted in terms of tourismbased exports' decline but will also create lasting contagion effects on the economic stability of any country. Moreover, thousands of people which are dependent for their livelihood on the tourism industry are now exploring other means of earning their basic needs. Thus, it can be implied that even when the COVID-19 is controlled, recovery from the deep-

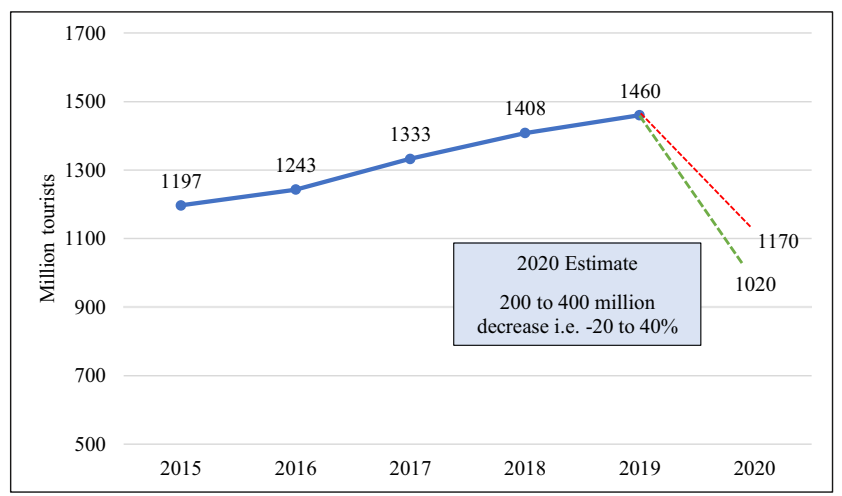

Fig. 8 Number of international tourists worldwide from 2015 to 2020 routed multi-sectoral ramifications will be a strenuous and time-consuming task (Ali 2020).

In Pakistan, the tourism industry was enjoying its peak during the last year as also expressed in the international reports of Conde Nast and Forbes, where the country was ranked as one of the top tourism destinations in 2020. It was anticipated that this year in the months of March and April, Pakistan will receive the highest number of international tourists, indicating significant economic uplifts. However, the unexpected outbreak of this novel viral disease has changed the entire course (Hussain 2020). The recent lockdown and rising COVID-19 cases in Pakistan have already curtailed the domestic travelling trend by 60-70\% (PTDC 2020). In another report by Asian Development Bank (ADB), it has been estimated that Pakistan's struggling tourism sector is likely to encounter an economic loss of approximately 6 million US\$ in 2020, based on the worst projections of expected cases.

\section{Trade and GDP}

As per the early estimations, this pandemic would result in a global economic recession of nearly 9 trillion US\$ in 2020 2021 fiscal year (Ahmed 2020). In the fiscal year (FY) 2019, the total GDP of Pakistan was calculated to be 38.6 trillion PKR at a growth rate of about $3.3 \%$. It was being anticipated that in the financial year 2020, the economic growth rate will decline to $2.6 \%$ (Haider 2020a, b; Nakhoda 2020a, b). The present-day estimations reported by Planning Commission of Pakistan predict an economic loss of about $10 \%$, i.e. 1.1 trillion PKR in the FY 2021 (World Bank 2020; Mustafa 2020). The impacted economic sectors in Pakistan are presented in Table 8.

Eight large financial capitals of the world, contributing about $45 \%$ to the global GDP and primary export partners of Pakistan having share of $40 \%$ in country's foreign revenue, are facing appalling economic pressure including the USA, the UK, Germany, France, Spain, Italy, Japan and Canada. 
Table 8 Production and economic loss in various sectors of the society due to COVID-19 outbreak in Pakistan

\begin{tabular}{lll}
\hline & Sectors & Economic loss \\
\hline 1 & Restaurants and hotels & $10 \%$ \\
2 & Recreation & $60 \%$ \\
3 & Information and communication & $20.3 \%$ \\
4 & Public transport & $70 \%$ \\
5 & Retail markets & $28.6 \%$ \\
6 & Electricity and electronic equipment repair & $60.9 \%$ \\
\hline
\end{tabular}

All these countries have been at the worst hit by the recent pandemic which calls for adverse ramifications on Pakistan's foreign revenue (Ashraf 2020; Faraz and Nasir 2020b; ITC 2020).

The trade pattern with four major partner countries including the USA, the UK, China and Germany has been depicted in Fig. 9. The data is collected over a period of 11 months from August 2019 to April 2020 so as to examine the pre- and postCOVID-19 scenario. It can be observed that in the case of the USA, the UK and Germany, there is a positive economic trend until February 2020 which can be attributed to their prevention from the COVID-19 outbreak, but the import and export flows with Pakistan have been analysed to depict a declining trend
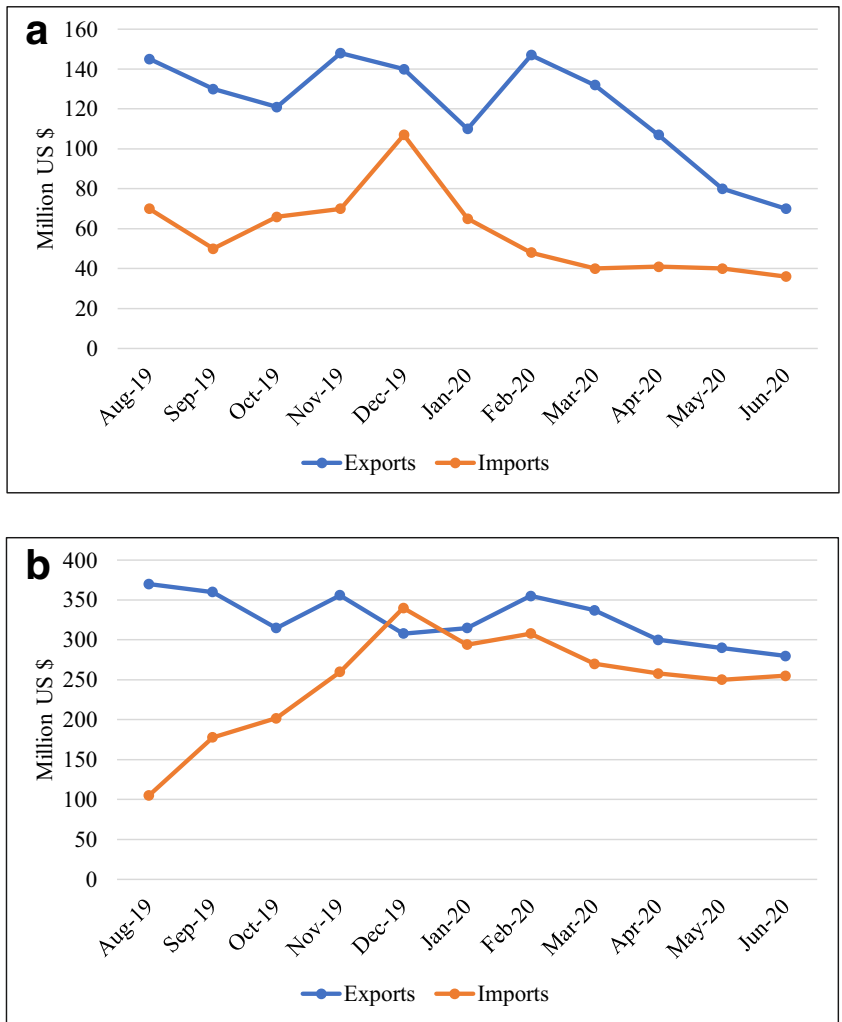

Fig. 9 Percent change in the import and export flow of Pakistan from August 2019 to June 2020. a Variations in the flow of exports and imports between Pakistan and the USA from August 2019 to June 2020. b Variations in the flow of exports and imports between Pakistan and the after March. In the case of China, the data for the month of February is unavailable due to the international trade ban, which was lifted in mid of March. As China has successfully controlled the pandemic, their economy is now enjoying a period of resurrection. During the spike of COVID-19 cases in China, i.e. in the month of February, Pakistan's export with other trade partners has increased drastically. With the current level of uncertainty in disease spread, accurate anticipation of future trends in the trading market is not practically possible. However, if the COVID-19 cases continue to increase with the same rate, restrictions in the industrial production, supply chain disruption and limited domestic and international transportation will deteriorate the economic structure of many developed countries of the world (Ashraf 2020; Faraz and Nasir 2020a; ITC 2020; Nakhoda 2020a, b).

\section{COVID-19: measures and lessons}

\section{Containment measures}

Almost all the countries of the Asia-Pacific have taken measures for the containment and/or mitigation of the spread of COVID-19. These included declaring a state of emergency, putting the country or major cities under lockdown or curfew.
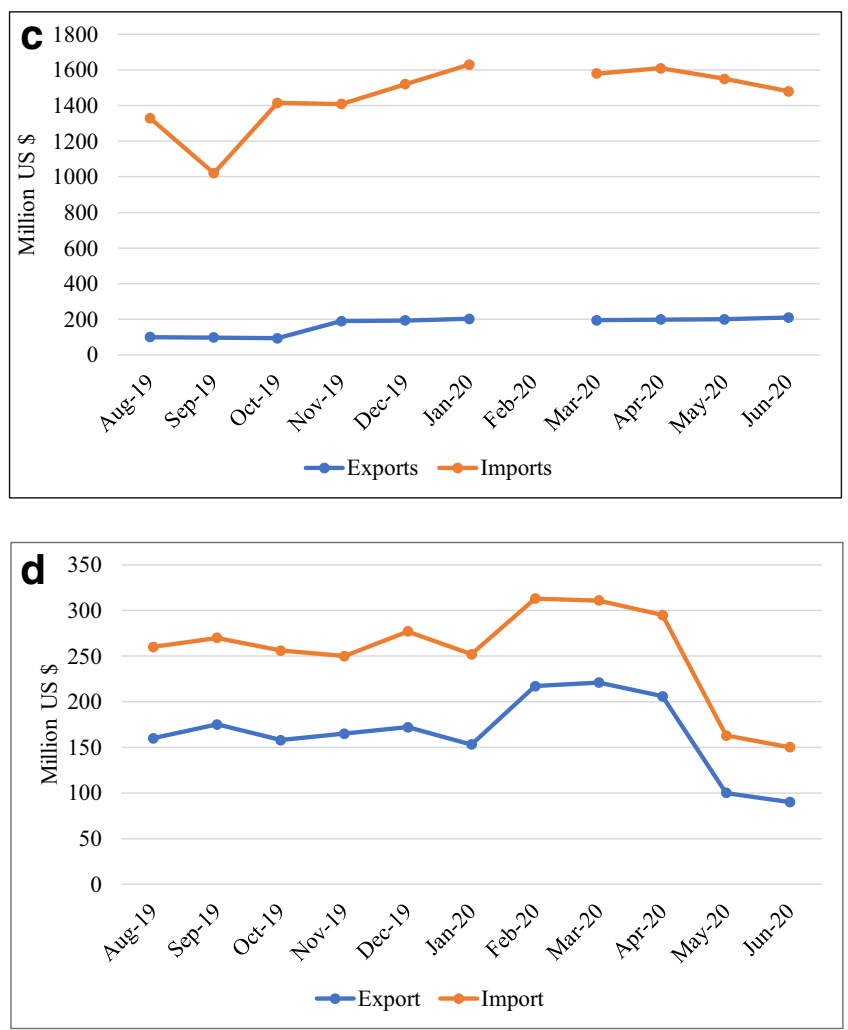

UK from August 2019 to June 2020. c Variations in the flow of exports and imports between Pakistan and China from August 2019 to June 2020. d Variations in the flow of exports and imports between Pakistan and Germany from August 2019 to June 2020 
Measures were taken to lower the risk of importing the virus through (a) full or partial closure of borders, (b) carrying out passenger screening at the airports (c) and introduction of travel restrictions or bans. Measures have also been taken to contain community transmission through (a) social distancing; (b) closing schools, colleges and universities; and (c) closing public places (Ocampo and Yamagishi 2020). However, only a few countries imposed fines or punishment for violating such isolation orders For example, Singapore penalized its citizens with a fine of up to $\mathrm{S} \$ 10,000$ or 6 months of imprisonment if anyone flouted the regulations. In contrary, only a quarter of the countries are mass testing the virus and are also tracing the potential contact which have been identified to be effective measures in containing the virus (The Guardian 2020).

\section{Macroeconomic stimulus}

Certain fiscal measures have been taken by the countries to save lives and livelihoods through stimulus packages so that the adverse socio-economic impact can be reduced. Countries have mainly prioritized their support to the health workers and paramedic staff. Measures are being taken to support businesses especially small- and medium-sized enterprises (SMEs). Furthermore, global and regional corporation is being engaged to combat COVID-19. Countries like Australia, Azerbaijan and New Zealand are contributing to the World Health Organization (WHO) fund. Japan has extended monetary support to the International Monetary Fund (IMF). These fiscal stimulus packages vary in size from country to country, ranging from 0.1 to $20 \%$ and more of GDP. Countries of the Asia-Pacific have also taken some monetary policy measures to avoid liquidity and credit crunch. Such measures are taken to complement the fiscal policy measures so that financial stability could be strengthened (IMF 2020). Countries are actively supporting their financial markets through reduction of debt burden on SMEs such as loan deferment, extensions and moratoriums are being allowed. The volatility of stock market is being eased through the temporary prohibition of short-selling, and reduction or exemption of fees for securities services (UNESCAP 2020; Xia et al. 2020).

\section{Conclusions and the way forward}

With the advent of novel super-contagious viral strain, the health sector around the globe has undergone significant developments not only at the treatment side but also at the disease prevention end. A similar trend is being observed in Pakistan too, where the public health system is mobilizing the relevant national instruments to deter rapid transmission rates of the recent pandemic. The regulatory agencies have apprehended lately that biological threats not only impact the environmental health but also pose abiding wide-scale impedance in socio-economic parameters. This necessitates comprehensive decision-making and directed efforts including multi-sectoral analysis of the negative externalities apart from the apparent human health-centred measures. This study has illustrated the short- and long-term prospects of the pandemic on the emerging economy, society and the environment in view of the current discussions. The COVID-19 outbreak and consequential lockdown have negatively impacted the GDP growth in Pakistan, i.e. lowering it from 33.2 to $2.2 \%$, while the global GDP growth rate is expected to decline from 3.1 to $2.8 \%$. The issues like local disruption of supply chains and national markets, poverty hike, employment layoffs, discontinuity of formal education of 47 million students and increased food prices are critical predominant challenges for the Government of Pakistan. On the other hand, drastic improvements in air quality index have been observed around the world including urban centres of Pakistan as a result of restricted transportation and industrial and agricultural activities which are attributed as major contributors of environmental pollution. This has helped in identifying the hotspots and activities which are major contributors towards environmental deterioration. Nevertheless, long-term environmental consequences in the form of increased burden on natural resources and over-exploitation may appear in future.

Many of the developing as well as developed countries having modernized and stable economic and health care sectors have drastically failed to limit the number of infected COVID cases as they might be lacking in-terms of timely prevention-planning and decision making. This has called for immediate need for Pakistan to learn lessons by identifying the loopholes in the measures taken by other countries and response of public authorities after initial failures have marked as unsatisfactory by the WHO, etc. This pandemic however has become a test case for Pakistan and the rest of the world for improving the preparedness and response mechanisms towards such pandemics. Greater mandates for planning, management, surveillance-monitoring, tracking-tracing, timely scientific advisories and responses to infectious disease outbreaks, accompanied by a substantial increase in global funding, are highly desirable. As the country is now approaching towards second wave of the pandemic, the core task is to widen the access to information and data which were not available previously to decisionmakers while dealing with the first wave. The virus status in the country is currently at a particular point in time where sequenced measures can significantly aid in controlling the spread unlike in the first wave, when welfare interventions had not been designed before time.

\section{The way forward}

In such unprecedented times, there is a dire need to develop economic recovery policies which have been embedded with 
inclusivity and sustainability. The policy packages which have been announced so far differ from country to country in terms of their aims. Some have prioritized their health sector to relieve its burden and are also dealing with the adverse impacts their economies are facing. On the other hand, some countries have decided to reopen their economies.

It is still very early to judge the effectiveness of these policies since there is a possibility lingering upon us that we might face another wave(s) of COVID-19. Apparently, the pro-active actions and timely decisions have helped to suppress the virus and to support small- and medium-scale businesses along with households to help save their lives and livelihoods. Another key aspect to be considered by decision-makers is that economic policy packages should be inclusive and sustainable.

Although the announcement of fiscal stimulus packages by countries have proven to be very helpful, but it will be more effective when resilience and preparedness is built in the community. As the current pandemic has clearly exposed the fragility of our economic, health and emergency preparedness systems so for future anticipations, to manage the crisis and lowering of impacts, it is important to strengthen social protection since it will act as an automatic stabilizer to help protect most vulnerable people.

The developing countries like Pakistan need to focus more objectively on the prevention is better than cure philosophy, and this is the right time to think proactively and keep them ready for any similar shocks in future. As their economies are already stressed and facing critical challenges due to their weaker political structure, limited fiscal space and capital markets, so they cannot afford to roll out the effective and timely stimulus packages like many developed countries.

South Asian region is facing an extreme climate emergency. Policy responses which are being taken to combat COVID-19 must simultaneously be assistive towards the acceleration of low-carbon transition, thereby supporting the climate change mitigation efforts. For instance, as the oil and gas prices are currently low, it can provide an opportunity for the implementation of broader carbon pricing mechanisms and the elimination of subsidies on fossil fuels.

Business sectors and their sound performance always play an integral role for the strengthening of any economy because of generations of monetary capitals and livelihoods. However, the firms and businesses must be made environmentally and socially responsible in terms of corporate social responsibility (CSR). They should provide their workers with decent living wages and other related benefits, and negative environmental externalities due to business operations should be internalized. As such a firm-wide three factors strategy, i.e., environmental, social and governance (ESG), will lead to increased transparency, responsibility and higher standards of reporting.

This current pandemic has helped us to realize that we cannot simply continue to consume our way, but we need to adopt sustainable lifestyles. During the essential lockdowns and isolation policies, the supply of goods and services have been reduced to only essentials, and people are able to differentiate between their needs and wants. Therefore, there should be an individual realization and adaptation of a sustainable lifestyle that will minimize the use of natural resources, consequently reducing our carbon footprints. The governments and firms can promote such sustainable goods, services and lifestyles by market-based instruments like voluntary ISO standards and eco-labelling.

This pandemic has emerged at a time where global cooperation was limited, but now this influential shock has taught the world about constructive exchange of ideas, cooperation and reaching the multitude of mutual solutions, which are imposable otherwise at their individual capacities. For example, in 2003 when the outbreak of severe acute respiratory syndrome (SARS) occurred, it taught us that information should be shared, responses should be coordinated and resources such as personal protective equipment, medicines and testing kits should be pooled.

The need of the hour is that global community should join hands to develop vaccines and medicines and to lift trade and tariff barriers especially on the medical equipment and supplies. Countries should also coordinate their fiscal and monetary policies along with concerted efforts to help indebted nations for the creation of fiscal space to help them mitigate the pandemic and to ensure their economic recovery, such that no one is left behind.

Authors' contributions Rizwan Rasheed: Conceptualization, visualization and methodology

Asfra Rizwan: Data curation, writing and formal analysis

Hajra Javed: Writing and original draft preparation

Faiza Sharif: Supervision and review of results

Asghar Zaidi: Administration, reviewing and editing

Data availability Not applicable.

\section{Compliance with ethical standards}

Competing interests The authors declare that they have no competing interests.

Ethics approval and consent to participate Not applicable.

Consent for publication Not applicable.

\section{References}

Abbasi S (2020) COVID-19: Pakistan's air quality improves amid lockdown. The Express Tribune. https://tribune.com.pk/story/2187870/ 1-covid-19-pakistans-air-quality-improves-amid-lockdown/. Accessed 19 September 2020

Abid NA (2020) Impact of COVID-19 on food security. The Nation. https://nation.com.pk/14-Apr-2020/impact-of-covid-19-on-foodsecurity. Accessed 16 July 2020 
Adhikari SP, Meng S, Wu YJ, Mao YP, Ye RX, Wang QZ, Sun C, Sylvia S, Rozelle S, Raat H, Zhou H (2020) Epidemiology, causes, clinical manifestation and diagnosis, prevention and control of coronavirus disease (COVID-19) during the early outbreak period: a scoping review. Infect dis poverty 9(1):1-12. https://doi.org/10.1186/ s40249-020-00646-x

Agency A (2020) Pakistan's health system braces for Covid-19 peak. The Express Tribune https://tribunecompk/story/2236875/3-pakistanshealth-system-braces-covid-19-peak/ Accessed 8 September 2020

Agriculture Marketing Information Service (AIMS) (2020) http://www. amis.pk/. Accessed 25 August 2020

Ahmad I (2020) Addressing the labour market crisis. The News. https:// www.thenews.com.pk/tns/detail/646002-addressing-the-labourmarket-crisis. Accessed 3 September 2020

Ahmed A (2020) COVID-19: Pakistan decides to gradually ease lockdown in coming days due to economic crisis. Gulf News. https:// gulfnews.com/world/asia/pakistan/covid-19-pakistan-decides-togradually-ease-lockdown-in-coming-days-due-to-economic-crisis1.71317229. Accessed 8 September 2020

Ahsan A (2020) COVID-19 - a wakeup call for higher education. Dawn News. https://www.dawn.com/news/1554232. Accessed 18 August 2020

Ali A (2020) Tourism and the pandemic. The News. https://www. thenews.com.pk/tns/detail/645694-tourism-and-the-pandemic. Accessed 1 September 2020

Ali I, Shah SA, Siddiqui N (2020) Pakistan confirms first two cases of coronavirus, govt says "no need to panic". Dawn News. https:// www.dawn.com/news/amp/1536792. Accessed 26 September 2020

Anjum A (2020) Food prices post-COVID-19 outbreak: the case of Punjab. In: Haque NU, Nayyab D (eds) PIDE COVID-19 Ebook, Pakistan, pp 60-63

Ashraf M (2020) Pakistan's exports in the post-Covid global marketplace. The Express Tribune. https://tribune.com.pk/story/2211764/ 6-pakistans-exports-post-covid-global-marketplace/. Accessed 6 September 2020

Ayra H (2020) Food security, the farmers of Pakistan and coronavirus. Arab News. https://www.arabnews.pk/node/1649496. Accessed 28 August 2020

Baldo V, Bertoncello C, Cocchio S, Fonzo M, Pillon P, Buja A, Baldovin $\mathrm{T}$ (2016) The new pandemic influenza $\mathrm{A} /(\mathrm{H} 1 \mathrm{~N} 1)$ pdm09 virus: is it really "new"? J Prev Med Hyg 57(1):19-22. https://doi.org/10. 15167/2421-4248/jpmh2016.57.1.574

Barro RJ, Ursúa JF Weng J (2020) The coronavirus and the great influenza pandemic: lessons from the "Spanish flu" for the coronavirus's potential effects on mortality and economic activity. National Bureau of Economic Research (No. w26866). https://doi.org/10. 3386/w26866

Cascella M, Rajnik M, Cuomo A, Dulebohn SC, Di Napoli R (2020) Features, evaluation and treatment coronavirus (COVID-19). StatPearls Publishing, Florida

Coibion O, Gorodnichenko Y, Weber M (2020) Labour markets during the COVID-19 crisis: a preliminary view. National Bureau of Economic Research (No. w27017). https://doi.org/10.3386/w27017

CREA (2020) Air quality before and after national lockdown during coronavirus disease (COVID-19) outbreak across Pakistan. Centre for Research on Energy and Clean Air (CREA). https:// energyandcleanair.org/air-quality-before-and-after-nationallockdown-during-coronavirus-disease-covid-19-outbreak-acrosspakistan/. Accessed 26 September 2020

Dawn News (2020) Fruit, vegetable exports hit by coronavirus. https:// www.dawn.com/news/1535190. Accessed 28 July 2020

Di Gennaro F, Pizzol D, Marotta C, Antunes M, Racalbuto V, Veronese N, Smith L (2020) Coronavirus diseases (COVID-19) current status and future perspectives: a narrative review. Int J Env Res Pub Health 17(8):2690. https://doi.org/10.3390/ijerph17082690
Duffin E (2020) Impact of the coronavirus pandemic on the global economy - statistics \& facts. Statista. https://www.statista.com/topics/ 6139/covid-19-impact-on-the-global-economy/. Accessed 20 September 2020

Faraz N, Nasir M (2020a) Economic impacts of COVID-19 through trade disruptions. In: Haque NU, Nayyab D (eds.) PIDE COVID-19 Ebook. Pakistan, pp 55-60

Faraz N, Nasir M (2020b) Labour market and COVID-19: provinciallevel analysis of vulnerable employment across sectors. In: Haque NU, Nayyab D (eds.) PIDE COVID-19 Ebook. Pakistan, pp 63-67

GoP (2020) COVID-19 live dashboard (Pakistan): national institute of health Islamabad. Government of Pakistan. http://covid.gov.pk/ stats/pakistan. Accessed 6 Decemeber 2020

Haider M (2020a) COVID-19: economy may face GDP loss of up to 4.64 percent. The News. https://www.thenews.com.pk/print/637732covid-19-economy-may-face-gdp-loss-of-up-to-4-64-percent. Accessed 1 September 2020

Haider M. (2020b) Pakistan's GDP may contract by more than $4 \%$ due to trade disruptions alone. Geo News. https://www.geo.tv/latest/ 280296-coronavirus-to-reduce-gdp-by-464-claims-study. Accessed 19 September 2020

Hassan TA, Hollander S, van Lent L, Tahoun A (2020) Firm-level exposure to epidemic diseases: COVID-19, SARS, and H1N1. National Bureau of Economic Research (No. w26971)

Henriques M (2020) Will COVID-19 have a lasting impact on the environment? BBC News. https://www.bbc.com/future/article/ 20200326-covid-19-the-impact-of-coronavirus-on-theenvironment. Accessed 29 September 2020

Hussain K (2020) In Pakistan, tourism industry feels corona fever. The Express Tribune. https://tribune.com.pk/story/2176351/2-pakistantourism-industry-feels-corona-fever/. Accessed 1 September 2020

Hyder A (2020) Short notes on the economy during the COVID-19 crisis. SSRN 2. https://doi.org/10.2139/ssrn.3632167

IGC (2020) COVID-19: Pakistan's preparations and response. International Growth Centre. https://www.theigc.org/blog/covid19-pakistans-preparations-and-response/. Accessed 17 September 2020

IMF (2020) Global financial stability report, April 2020: Markets in the Time of COVID-19 https://wwwimforg/en/Publications/GFSR/ Issues/2020/04/14/Global-Financial-Stability-Report-April-202049020 Accessed 17 September 2020

Imran M (2020). CGSS holds online conference on impact of COVID-19 on agriculture sector. The News. https://www.thenews.com.pk/ print/647969-cgss-holds-online-conference-on-impact-of-COVID19-on-agriculture-sector. Accessed 18 August 2020

Inoue H, Todo Y (2020) The propagation of the economic impact through supply chains: the case of a mega-city lockdown against the spread of COVID-19. SSRN 3564898. https://doi.org/10.2139/ssrn. 3564898

ILO (International Labour Organization) (2020a) COVID-19: How social and economic sectors are responding. https:/www.ilo.org/global/ about-the-ilo/newsroom/news/WCMS 742203/lang\%2D\%2Den/ index.html. Accessed 19 August 2020

ILO (International Labour Organization) (2020b) COVID-19 impact on the collection of labour market statistics. https://ilostat.ilo.org/topics/ covid-19/covid-19-impact-on-labour-market-statistics/. Accessed 21 July 2020

International Trade Centre (ITC) (2020) http://www.intracen.org/layouts/ CountryTemplate .aspx ?pageid $=47244645034 \& i d=47244652405$. Accessed 6 September 2020

Junaidi I (2020) Association warns of health sector collapse as medical professionals contract COVID-19. Dawn News. https://www.dawn. com/news/1548980. Accessed 27 August 2020

Kermani S (2020) Coronavirus: youthful Pakistan appears to avoid worst of pandemic. BBC News https://wwwbbccom/news/world-asia53742214 Accessed 8 December 2020 
Labour Force Survey 2017-18 (2018) http://www.pbs.gov.pk/content/ labour-force-survey-2017-18-annual-report. Accessed 22 July 2020

Lai CC, Shih TP, Ko WC, Tang HJ, Hsueh PR (2020) Severe acute respiratory syndrome coronavirus 2 (SARS-CoV-2) and corona virus disease-2019 (COVID-19): the epidemic and the challenges. Int J Antimicrob Agents 105924:105924. https://doi.org/10.1016/j. ijantimicag.2020.105924

Li H, Liu SM, Yu XH, Tang SL, Tang CK (2020) Coronavirus disease 2019 (COVID-19): current status and future perspective. Int J Antimicrob Agents 105951:105951. https://doi.org/10.1016/j. ijantimicag.2020.105951

Lilley A, Lilley M, Rinaldi G (2020) Public health interventions and economic growth: revisiting the Spanish flu evidence. SSRN 3590008. https://doi.org/10.2139/ssrn.3590008

Liu WJ, Bi Y, Wang D, Gao GF (2018) On the centenary of the Spanish flu: being prepared for the next pandemic. Virol Sin 33(6):463-466. https://doi.org/10.1007/s12250-018-0079-1

Liu Y, Gayle AA, Wilder-Smith A, Rocklöv J (2020) The reproductive number of COVID-19 is higher compared to SARS coronavirus. J Travel Med 27(2):1-4. https://doi.org/10.1093/jtm/taaa021

MacIntyre CR (2014) The discrepant epidemiology of Middle East respiratory syndrome coronavirus (MERS-CoV). Environ Syst Decis 34(3):383-390. https://doi.org/10.1007/s10669-014-9506-5

Malik A (2020) Controlling coronavirus. The News. https://www. thenews.com.pk/tns/amp/606911-controlling-coronavirus. Accessed 27 September 2020

Malik K, Meki M, Morduch J, Ogden T, Quinn S, Said F (2020) COVID19 and the future of microfinance: evidence and insights from Pakistan. Oxford Rev Econ Pol. https://doi.org/10.2139/ssrn. 3615077

Mamun MA, Ullah I (2020) COVID-19 suicides in Pakistan, dying off not COVID-19 fear but poverty?-the forthcoming economic challenges for a developing country. Brain Behav Immun 87:163-166. https://doi.org/10.1016/j.bbi.2020.05.028

McKee M, Stuckler D (2020) If the world fails to protect the economy, COVID-19 will damage health not just now but also in the future. Nat Med 26(5):640-642. https://doi.org/10.1038/s41591-020-0863$\mathrm{y}$

Mustafa K (2020) Impact of COVID-19 pandemic: Pak GDP to contract by $1.6 \mathrm{pc}$ in current fiscal, says Economist Intelligence Unit. The News. https://www.thenews.com.pk/print/656244-impact-ofCOVID-19-pandemic-pak-gdp-to-contract-by-1-6pc-in-currentfiscal-economist-intelligence-unit. Accessed 19 August 2020

Nakhoda A (2020a) COVID-19 poses great trade challenge. The Express Tribune https://ribune.com.pk/story/2218477/2-covid-19-posesgreat-trade-challenge/. Accessed 8 September 2020

Nakhoda A (2020b) Pakistan's top export destinations have been devastated by COVID-19. What does it mean for our trade? Dawn News. https://www.dawn.com/news/1556301/pakistans-top-exportdestinations-have-been-devastated-by-covid-19-what-does-itmean-for-our-trade. Accessed 6 September 2020

Nasir M, Faraz N, Khalid M (2020) Sectoral analysis of the vulnerably employed : COVID-19 and the Pakistan's labour market. In: Haque NU, Nayyab D (eds) PIDE COVID-19 Ebook, Pakistan, pp 32-37

Nicola M, Alsafi Z, Sohrabi C, Kerwan A, Al-Jabir A, Iosifidis C, Agha M, Agha R (2020) The socio-economic implications of the coronavirus and COVID-19 pandemic: a review. Int J Surg 78:185-193. https://doi.org/10.1016/j.ijsu.2020.04.018

NIH (2020) National action plan for preparedness \& response to Corona virus disease (COVID-19) Pakistan. National Institute of Health Pakistan. https//www.nih.org.pk/wp-content/uploads/2020/02/ NAP-covid-19_AL@version-3-date-12-2-2020-withannexures.pdf. Accessed 27 September 2020

Ocampo L, Yamagishi K (2020) Modelling the lockdown relaxation protocols of the Philippine government in response to the COVID-19 pandemic: an intuitionistic fuzzy DEMATEL analysis. Socio Econ
Plan Sci 100911:100911. https://doi.org/10.1016/j.seps.2020. 100911

Organization for Economic Cooperation and Development (OECD) (2020) Evaluating the initial impact of COVID-19 containment measures on economic activity. http://wwwoecdorg/coronavirus/ policy-responses/evaluating-the-initial-impact-of-covid-19containment-measures-on-economic-activity-b1f6b68b/ Accessed 17 September 2020

Pakistan Today (2019) Health spending less than one percent of GDP for decades. https://www.pakistantoday.com.pk/2019/07/01/healthspending-less-than-one-percent-of-gdp-for-decades/. Accessed 17 September 2020

Pakistan Today (2020) Lahore air quality improves due to pandemic induced lockdown. https://www.pakistantoday.com.pk/2020/04/ 14/lahore-air-quality-improves-due-to-pandemic-inducedlockdown/. Accessed 19 September 2020

Pakistan Tourism Development Cooperation (PTDC) (2020) http://www. tourism.gov.pk/covid 19 main new.html. Accessed 1 September 2020

Qazi AJ (2020) Covid, climate \& Pakistan. Dawn News https:// wwwdawncom/news/1548230 Accessed 29 September 2020

Rothan HA, Byrareddy SN (2020) The epidemiology and pathogenesis of coronavirus disease (COVID-19) outbreak. J Autoimmun 102433: 102433. https://doi.org/10.1016/j.jaut.2020.102433

Saeed T (2020) Digital divide worsens Pakistan education sector amid COVID-19. Technology Times. https://www.technologytimes.pk/ 2020/05/05/digital-divide-worsens-pakistan-education-sector-amidCOVID-19/. Accessed 10 September 2020

Sahin AR, Erdogan A, Agaoglu PM, Dineri Y, Cakirci AY, Senel ME et al (2020) 2019 novel coronavirus (COVID-19) outbreak: a review of the current literature. Eurasian J Med Oncol 4(1):1-7. https://doi. org/10.14744/ejmo.2020.12220

Saqlain M, Munir MM, Ahmed A, Tahir AH, Kamran S (2020) Is Pakistan prepared to tackle the coronavirus epidemic? Drugs Ther Perspect 36:213-214. https://doi.org/10.1007/s40267-020-00721-1

Sharif A, Aloui C, Yarovaya L (2020) COVID-19 pandemic, oil prices, stock market, geopolitical risk and policy uncertainty nexus in the US economy: fresh evidence from the wavelet-based approach. Int Rev Financ Anal 101496. https://doi.org/10.1016/j.irfa.2020. 101496

Siddiqi SA (2020) COVID-19 education response. The News. https:/ www.thenews.com.pk/print/645803-covid-19-education-response. Accessed 9 September 2020

Stratford C (2020) Pakistan ill-equipped to fight COVID-19: healthcare workers. Al Jazeera. https://www.aljazeera.com/news/2020/04/ pakistan-ill-equipped-fight-covid-19-healthcare-workers200404095933357.html accessed 27 august 2020

Sun J, He WT, Wang L, Lai A, Ji X, Zhai X, Li G, Suchard MA, Tian J, Zhou J, Veit M (2020) COVID-19: epidemiology, evolution, and cross-disciplinary perspectives. Trends Mol Med 26(5):483-495. https://doi.org/10.1016/j.molmed.2020.02.008

The Guardian (2020) 10 key lessons for the future to be learned from fighting COVID-19. https://www.theguardian.com/world/2020/ may/01/10-key-lessons-for-future-learned-fighting-covid-19coronavirus-society. Accessed 20 September 2020

UNICEF (2018). National Nutrition Survey. https://www.unicef.org/ pakistan/national-nutrition-survey-2018. Accessed 15 August 2020

United Nations Economic and Social Commission for Asia and the Pacific (UNESCAP) (2020) Combating COVID-19 in Asia and the Pacific: measures, Lessons and the Way Forward. United Nations ESCAP. https://www.unescap.org/sites/default/files/ Policy\%20brief_MPFD_Combating\%20COVID-19\%20in\% 20 Asia $\% 20$ and $\% \overline{2} 0$ the $\% 20$ Pacific $\% 20$ updated.pdf. Accessed 25 August 2020

United Nations World Tourism Organization (UNWTO) (2020). https:// www.unwto.org/tourism-COVID-19. Accessed 27 August 2020 
Verikios G (2020) The dynamic effects of infectious disease outbreaks: the case of pandemic influenza and human coronavirus. Socio-Econ Plan Sci 100898:100898. https://doi.org/10.1016/j.seps.2020. 100898

Waris A, Khan AU, Ali M, Ali A, Baset A (2020) COVID-19 outbreak: current scenario of Pakistan. New Microbe New Infect 35:100681. https://doi.org/10.1016/j.nmni.2020.100681

WEF (2020) COVID-19: Pakistan's 'green stimulus' scheme is a winwin for the environment and the unemployed. World Economic Forum (WEF) https://www.weforum.org/agenda/2020/04/greenstimulus-pakistan-trees-coronavirus-covid10-enviroment-climatechange/. Accessed September 19, 2020

WHO (2020a) Global Spending on Health: A World in Transition. https:// www.who.int/health_financing/documents/health-expenditurereport-2019.pdf?ua=1. Accessed 31 August 2020

WHO (2020b) WHO Coronavirus Disease (COVID-19) Dashboard. https://covid19.who.int/. Accessed 6 Decemeber 2020

World Bank (2020) World Bank Fast-Tracks Support for COVID-19 (Coronavirus) Response to Pakistan. https://www.worldbank.org/ en/news/press-release/2020/04/02/world-bank-fast-tracks-supportfor-COVID-19-coronavirus-response-to-pakistan. Accessed 19 August 2020

World Economic Outlook (WEO) (2020) The great lockdown. https:// www.imf.org/en/Publications/WEO/Issues/2020/04/14/weo-april2020 Accessed 16 August 2020
Xia H, An W, Li J, Zhang ZJ (2020) Outlier knowledge management for extreme public health events: understanding public opinions about COVID-19 based on microblog data. Socio Econ Plan Sci 100941. https://doi.org/10.1016/j.seps.2020.100941

Zhou P, Yang XL, Wang XG, Hu B, Zhang L, Zhang W, Si HR, Zhu Y, Li B, Huang CL, Chen HD, Chen J, Luo Y, Guo H, Jiang RD, Liu MQ, Chen Y, Shen XR, Wang X, Zheng XS, Zhao K, Chen QJ, Deng F, Liu LL, Yan B, Zhan FX, Wang YY, Xiao GF, Shi ZL (2020) A pneumonia outbreak associated with a new coronavirus of probable bat origin. Nature 579(7798):270-273. https://doi.org/10. 1038/s41586-020-2012-7

Zhu N, Zhang D, Wang W, Li X, Yang B, Song J, Zhao X, Huang B, Shi W, Lu R, Niu P, Zhan F, Ma X, Wang D, Xu W, Wu G, Gao GF, Tan W, China Novel Coronavirus Investigating and Research Team (2020) A novel coronavirus from patients with pneumonia in China, 2019. N Engl J Med 382:8-733. https://doi.org/10.1056/ NEJMoa2001017

Zu ZY, Jiang MD, Xu PP, Chen W, Ni QQ, Lu GM, Zhang LJ (2020) Coronavirus disease 2019 (COVID-19): a perspective from China. Radiology 296:2-E25. https://doi.org/10.1148/radiol.2020200490

Publisher's note Springer Nature remains neutral with regard to jurisdictional claims in published maps and institutional affiliations. 